\title{
The dynamics of the plankton community on Lake Siombak, a tropical tidal lake in North Sumatra, Indonesia
}

\author{
AHMAD MUHTADI ${ }^{1, \bullet}$, AHYAR PULUNGAN ${ }^{1}$, NURMAIYAH ${ }^{1}$, AZIZAH FADLHIN ${ }^{1}$, PUPUT MELATI $^{1}$, \\ RENI ZULIKA SINAGA ${ }^{1}$, RAIHAN ULIYA ${ }^{1}$, MIFTAH RIZKI ${ }^{1}$, NUR ROHIM ${ }^{1}$, DAYUN IFANDA ${ }^{1}$, \\ RUSDI LEIDONALD ${ }^{1}$, HESTI WAHYUNINGSIH ${ }^{2}$, QADAR HASANI ${ }^{3}$ \\ ${ }^{1}$ Department of Aquatic Resources Management, Faculty of Agriculture, Universitas Sumatera Utara. J1. Prof. A. Sofyan No. 3, Medan 20155, North \\ Sumatra, Indonesia. Tel./fax.: +62-61-8213236, ^email: ahmad.muhtadi@usu.ac.id \\ ${ }^{2}$ Department of Biology, Faculty of Mathematics and Natural Sciences, Universitas Sumatera Utara. Jl. Bioteknologi No. 1, Medan 20155, North \\ Sumatra, Indonesia. \\ ${ }^{3}$ Department of Aquatic Resources, Faculty of Agriculture, Universitas Lampung. J1. Prof. Sumantri Brojonegoro No. 1, Bandar Lampung 35145, \\ Lampung, Indonesia
}

Manuscript received: 6 June 2020. Revision accepted: 23 July 2020.

\begin{abstract}
Muhtadi A, Pulungan A, Nurmaiyah, Fadlhin A, Melati P, Sinaga RZ, Uliya R, Rizki M, Rohim N, Ifanda D, Leidonald R, Wahyuningsih H, Hasani Q. 2020. The dynamics of the plankton community on Lake Siombak, a tropical tidal lake in North Sumatra, Indonesia. Biodiversitas 21: 3707-3719. The tidal lake is a very dynamic estuary ecosystem and very vulnerable to environmental stresses and disturbances. Plankton is an aquatic organism that is very easily affected by environmental pressures and disturbances. This study aimed to reveal the phenomenon of plankton dynamics in tropical tidal lakes in Indonesia. The study was conducted at Siombak Lake from Sept 2018 toAugust 2019. Data were collected at high and low tides every month during the full month. The data analysis included plankton abundance, diversity index, and the relationship between water quality and plankton with PCA and succession analysis. The results showed that in Siombak Lake was found 66 genera which consisted of 54 phytoplankton genera and 12 zooplankton genera. Plankton abundance is higher in parts of the lake (stations 1-8) than in the river (stations 9-11) at both high and low tide. Temporally it shows that plankton abundance is higher in the rainy season (Feb-August, outside May) than in the rainy season (Sept-Jan, and May). Spatially, plankton in Siombak Lake at high tide is more influenced by TSS, phosphate, and salinity, while at low tide, it is influenced by TSS, Water transparency, BOD, silicate, salinity, and dissolved oxygen. Temporally, plankton in Siombak Lake at high tide is more influenced by salinity, conductivity, Debit, TSS, and salinity, while at low tide, it is influenced by salinity, conductivity, turbidity, TSS, TDS, DO, BOD, and COD. Based on the plankton Frontier succession graph, it shows that Siombak Lake is included in stage 1 and stage 2. Stage 1 occurs before the rainy season (August-September) and the peak of the dry season (MarchApril).
\end{abstract}

Keywords: Biodiversity, coastal lake, North Sumatra, plankton, succession

\section{INTRODUCTION}

The tidal lake is a very dynamic estuary ecosystem and is very susceptible to environmental stresses and disturbances (Pérez-Ruzafa et al. 2011; Cutrim et al. 2019; Torres-Bejarano et al. 2020). Its location between land and sea is very possible to be influenced by both freshwater and seawater (Kjerfve 1994; Pérez-Ruzafa et al. 2011; de Barros et al. 2014; Medina-Gómez et al. 2014). This ecosystem acts as a filter and preserves nutrients and organic and inorganic materials despite fluctuations due to the influence of low and high tides (Sujitha et al. 2017; Ratnayake et al. 2018; Pérez-Ruzafa et al. 2019). Tidal lakes are very vulnerable to nutrient enrichment from surface runoff (both fresh and seawater), groundwater, and atmospheric sensitivity (Rodellas et al. 2018; Mentzafou and Dimitriou 2019; Pérez-Ruzafa et al. 2019). This nutrient enrichment creates an environmental gradient changing the chemical and biological properties of the lagoon directly or indirectly (Mentzafou and Dimitriou 2019; Pérez-Ruzafa et al. 2019). This will result in high biomass accumulation and drastic changes in the structure of the plankton food network and ecosystem function (Hemraj et al. 2017; Bueno-Pardo et al. 2018; Cutrim et al. 2019; Pérez-Ruzafa et al. 2019; Pérez-Ruzafa et al. 2020).

Salinity and nutrient availability are considered as the most important factors that determine the composition and size of the phytoplankton structure (Srichandan et al. 2015; Pratiwi et al. 2018a; Pratiwi et al. 2018b; Gamito et al. 2019; Yang et al. 2019), and also affect community dynamics zooplankton. Salinity is a major structuring factor that directly influences zooplankton diversity attributes (Paturej et al. 2017). The plankton community is a biotic community that is very sensitive to the changes and dynamics of water quality, especially nutrients, including salinity in the estuary or coastal lagoon ecosystem.

Siombak Lake is one of the tropical tidal lakes in Indonesia. Although it is quite far from the sea (as far as $7.5 \mathrm{~km}$ from the Belawan Sea, the Malacca Strait), the tidal influence is very strong in Lake Siombak. This can be seen from the elevation of sea levels that varies according to tidal fluctuations in Belawan with a span of 2 hours in Lake 
Siombak (Muhtadi et al. 2017a). Lake Siombak was originally a dredged area for the construction of the Belawan Medan Tanjung Morawa Toll Road (Belmera) in the mid of 1980s (Muhtadi et al. 2016). However, over time the area was filled with water and formed a large puddle reaching 28 hectares (Muhtadi et al. 2017a).

Furthermore, this lake developed and functioned as a polder system or water system in the region. The polder system is used to collect seawater during high tide so that it can prevent flooding. Along with the increase in time by the connection through the river to the Belawan Sea, many fish and crustaceans entered the waters of Lake Siombak. Therefore, the tidal lake is a fishing ground for the surrounding community (Muhtadi et al. 2016). Also, the location of the lake that is close to the Medan city landfill, and the circulation of lake water from Belawan waters is very potential for the input of urban waste and the landfill. Urban waste, especially from households, generally contains organic material that has the potential to become nutrients.

Various plankton studies have been carried out in lake waters, both natural and artificial lakes, such as Lake Pondok Lapan (Muhtadi et al. 2015), Lake Toba (Rahman et al. 2016), Lake Ebony (Pratiwi et al. 2018a), Lake Matano (Sulawesty 2019), Lake Maninjau (Sulastri et al. 2019). Some research on estuarine and mangrove waters has been widely carried out and reported, such as the Mahakam Delta, East Kalimantan (Effendi et al. 2016), Belawan Estuary (Dimenta et al. 2018), Segara Anakan, Central Java (Dewi et al. 2019; Wiyarsih et al. 2019); including bay and coastal waters, such as in Gorontalo Bay (Kadim et al. 2018), Sunda Strait (Takarina et al. 2019), Banten Bay, Lampung and Jakarta (Sidabutar et al. 2016; Damar et al. 2020). However, no research has been reported on the dynamics of plankton in tidal lakes in Indonesia. Meanwhile, tidal lakes abroad have been widely reported, for example, Yewa Lagoon, Nigeria (Effiong and Inyang 2016), Términos Lagoon, Mexico (Conan et al. 2017), Chilika Lake, India (Srichandan et al. 2015; Sahu et al. 2016 ; Mukherjee et al. 2018), Abduş Lagoon, Turkey (Yilmaz et al. 2018), Temperate coastal lagoon in Ria de Aveiro, Portugal (Bueno-Pardo et al. 2018), coastal lakes in Baltic Sea (Obolewski et al. 2018 ), a coastal lagoon in northern Brazil (Cutrim et al. 2019), Mediterranean lake (Mentzafou and Dimitriou 2019). Therefore, this study is the answer to the case on the characteristics of plankton dynamics in tropical tidal lakes in Indonesia. The existence of dynamics and changes in the composition of plankton types due to the physical-chemical conditions of the waters are referred to as succession (Adesalu and Nwankwo 2011; Romagnan et al. 2015; Chen et al. 2016). The succession shows the effect of environmental fluctuations on the plankton community including different species and different times (Romagnan et al. 2015; Chen et al. 2016). Pratiwi et al. (2018a) state that succession is a change in the relative abundance of species in a community. In this regard, research is needed to examine the relationship between plankton succession and changes in water quality for the benefit of Siombak Lake management. Thus, this study aimed to (i) describe the description of the dynamics of plankton spatially and temporally in the lake waves; (ii) water quality characteristics that affect plankton abundance, and (iii) provide information on the succession of plankton that occurs in the lake of the tides.

\section{MATERIALS AND METHODS}

\section{Study area}

The study was conducted from September 2018 to August 2019 in the Lake Siombak waters of the Medan Marelan Sub-district, Medan City, North Sumatra Province, Indonesia. The tools used in this study were GPS, Vandor water sampler, plankton net with a mesh size of 30 $\mu \mathrm{m}, \mathrm{pH}$ meter, thermometer, DO meter, Secchi disk, sample bottle, spectrophotometer, cuvette bottle, centrifuge, vacuum pump, stationery, and laptop. The materials used were water samples, $\mathrm{MnSO}_{4}, \mathrm{H}_{2} \mathrm{SO}_{4}, \mathrm{KOH}-$ $\mathrm{KI}, \mathrm{Na}_{2} \mathrm{~S}_{2} \mathrm{O}_{3}$, Amylum, distilled water, duct tape, gloves, rope, aluminum foil, acetone solution, label paper, and tissues. Map of Research Locations can be seen in Figure 1.

Plankton identification is carried out in the Integrated Laboratory of the Program of Aquatic Resources Management, Faculty of Agriculture, University of Sumatera Utara, Medan, Indonesia. Water quality analysis was carried out at Medan Environmental Health Technical Laboratory and Medan Industrial Standardization Laboratory, Medan City, Indonesia.

\section{Procedures of sampling}

Plankton samples were taken using a plankton net tool vertically from a depth of $2 \mathrm{~m}$ that is pulled up to the surface (Hasani et al. 2012). Filtered sample water is then poured into a $50 \mathrm{ml}$ polyethylene bottle. Furthermore, the plankton sample was preserved with a Lugol $4 \%$ solution and then stored in a black plastic polybag, then counted and identified. The samples taken are at high and low tide.

The physicochemical parameters measured in situ are directly measured before taking a plankton water sample. Water samples were taken using the Vandorn water sampler. The measured water sample is a sample that is mixed from the surface depth $(50 \mathrm{~cm})$, middle, and bottom of the water, except the parameters of temperature, salinity, and $\mathrm{pH}$ which are measured each depth of $1 \mathrm{~m}$. Water quality data measured in the laboratory were then mixed and taken as much as 1) $500 \mathrm{ml}$ (without preservatives) for TSS samples, 2) $1000 \mathrm{ml}$ for $\mathrm{BOD}, \mathrm{COD}, \mathrm{NO}_{3}$ samples, total phosphate, total nitrogen, and silica (stored at $4^{\circ} \mathrm{C}$ ). The measurement of physical and chemical parameters of waters refers to Rice et al. (2017).

\section{Plankton identification}

Plankton abundance was calculated using sedgewick rafter counting (SRC) at a magnification of $10 \times 40$. The enumeration was carried out using a binocular microscope model Olympus CH-2. Phytoplankton's morphological identification uses the reference book Pennak (1989), Tomas (1997), Bellinger and Siegee (2010). 

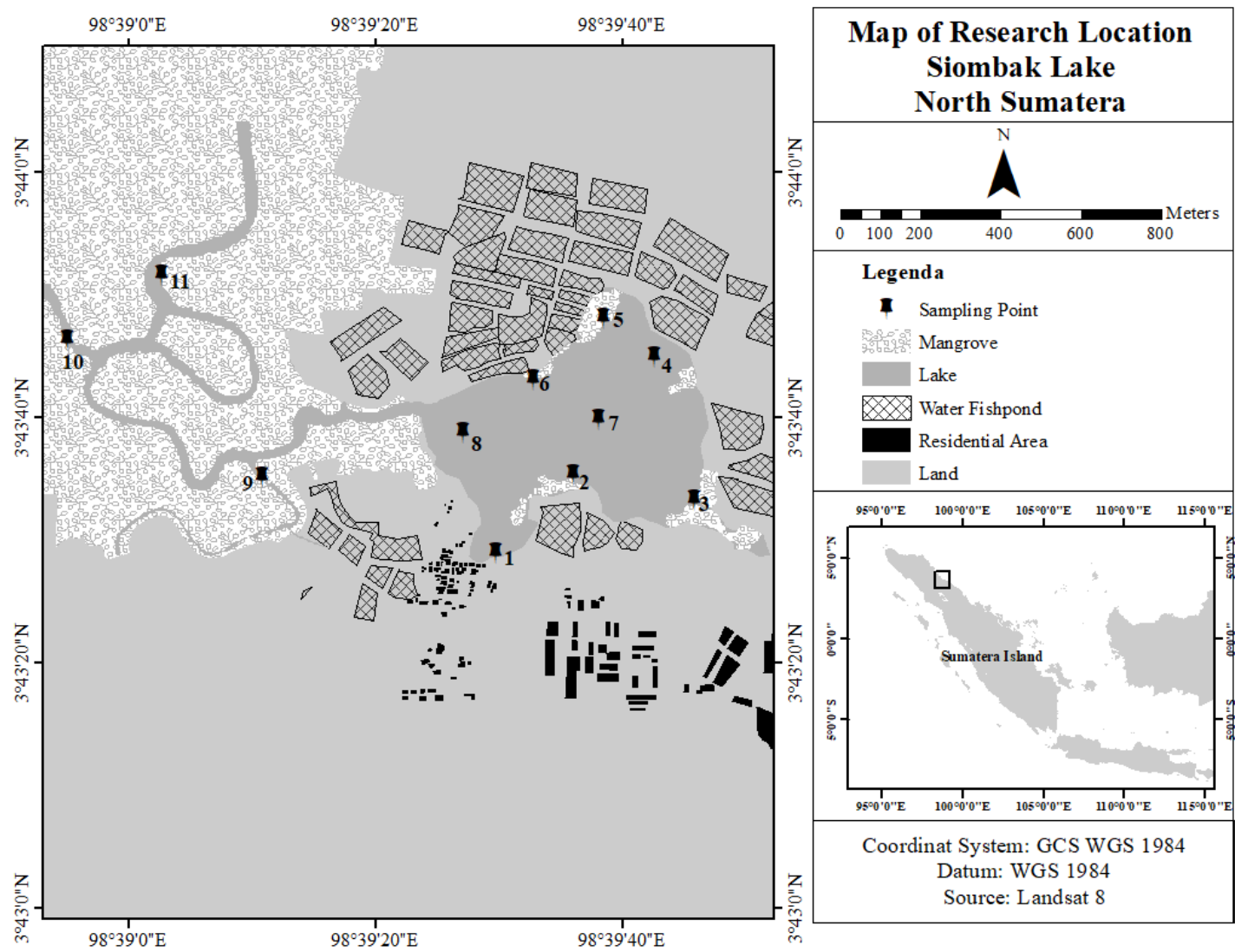

Figure 1. Location of Siombak Lake in Medan Marelan Sub-district, Medan City, North Sumatra Province, Indonesia; point 1 $\left(3^{\circ} 43^{\prime} 29.44^{\prime \prime} \mathrm{N}, 98^{\circ} 39^{\prime} 29.51^{\prime \prime E}\right)$; point $2\left(3^{\circ} 43^{\prime} 36.41^{\prime \prime} \mathrm{N}, 98^{\circ} 39^{\prime} 38.01^{\prime \prime E}\right)$; point $3\left(3^{\circ} 433^{\prime} 33.44^{\prime \prime} \mathrm{N}, 98^{\circ} 39^{\prime} 45.69^{\prime \prime} \mathrm{E}\right)$; point $4\left(3^{\circ} 43^{\prime} 44.31^{\prime \prime} \mathrm{N}\right.$,

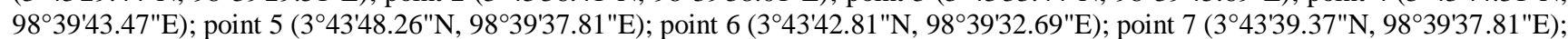
point $8\left(3^{\circ} 43^{\prime} 39.34^{\prime \prime} \mathrm{N}, 98^{\circ} 39^{\prime} 25.54^{\prime \prime} \mathrm{E}\right)$; point $9\left(3^{\circ} 43^{\prime} 32.92^{\prime \prime} \mathrm{N}, 98^{\circ} 39^{\prime} 13.23^{\prime \prime} \mathrm{E}\right)$; point $10\left(^{\circ} 43^{\prime} 46.96^{\prime \prime} \mathrm{N}, 98^{\circ} 38^{\prime} 54.96^{\prime \prime} \mathrm{E}\right)$; point 11 $\left(3^{\circ} 43^{\prime} 51.95^{\prime \prime} \mathrm{N}, 98^{\circ} 39^{\prime} 2.09^{\prime \prime} \mathrm{E}\right)$; and the detected sites

\section{Data analysis}

\section{Plankton abundance}

Plankton abundance is expressed in cells per $\mathrm{m}^{3}$ calculated by the formula (Hasani et al. 2012):

$$
N i=\frac{T}{L} X \frac{P}{p} X \frac{V}{v} X \frac{1}{w}
$$

Where: N: Number of per liter plankton (cell / L for phytoplankton and individual / L for zooplankton), and then change to cell $/ \mathrm{m}^{3}$ (multiplied by $10^{6}$ ); N: Cover glass area $\left(\mathrm{mm}^{2}\right)$; L: Wide field of view $\left(\mathrm{mm}^{2}\right)$; $\mathrm{P}$ : number of plankton that are chopped (cell or individual); $\mathrm{p}$ : Number of a field of view observed; V: Volume of filtered plankton sample (ml); v: Vol. plankton under the glass cover (ml); w: Vol. filtered plankton samples (liters).

\section{Diversity index}

Succession charts can be interpreted using the Shannon Wiener diversity index $\left(\mathrm{H}^{\prime}\right)$ of biodiversity, species equality (E), and Simpson index (D) dominance. Shannon Wiener's diversity index equation is as follows (Krebs 2014):

$$
\mathrm{H}^{\prime}=-\left(\sum \mathrm{pi} \ln \mathrm{pi}\right)
$$

Where: $\mathrm{H}^{\prime}$ : species diversity index; ni: Number of individuals of each species; N: Number of all individuals; $\mathrm{Pi}$ : Probability is important for each species $=\mathrm{ni} / \mathrm{N}$.

Uniformity is the individual composition of each species in a community (Krebs 2014). The uniformity index $(E)$ is expressed by the following equation:

$$
\mathrm{E}=\mathrm{H}^{\prime} / \mathrm{H} \max
$$

Where: E: Shannon-Wienner uniformity index; $\mathrm{H}$ : Species balance; H max: maximum diversity index $(\ln S)$; S: Total number of species.

The dominance index is used to obtain information about the types of fish that dominate in a community in each habitat. The dominance index describes the composition of species in the community. The dominance index is calculated according to the Simpson index (Odum and Barrett 2005):

$$
\mathrm{C}=\sum\left(\frac{n i}{N}\right)^{2}
$$

Where: C: dominance Index; ni: The number of individuals of each species; $\mathrm{N}$ : Total individual community. 


\section{Analysis of the relationship between phytoplankton and} water quality

The analysis of the relationship between plankton and water quality is done by multiple regression analysis and correlation tests. Multiple regression analysis and correlation test use Microsoft Office Excel software version 2016. There are 15 parameters of water quality and added abundance of phytoplankton or zooplankton used in looking at factors that affect the abundance of phytoplankton and or zooplankton. The parameter selection is then performed using the lack of pit to determine what parameters affect the abundance of phytoplankton and or zooplankton. The lack of fit method is one way to select the dependent factor $(\mathrm{X})$ against the independent factor $(\mathrm{Y})$ by looking at the $\mathrm{P}$-value in the Anova table of multiple linear regression (Harlan 2018). P-value below 0.05, which will be included in the factor-dependent criteria (X), affects the independent factor $(\mathrm{Y})$.

\section{Plankton succession}

The succession analysis includes determining stages by using Frontier succession charts, diversity indexes (diversity, uniformity, and dominance), and summed difference index (SDI). Frontier succession graph is a temporal presentation of the value of the proportion of species abundance and rank (Frontier 1985). Three kinds of guideline graphs illustrate the stage, level of adaptation, or community succession created by the rank frequency method presented on a logarithmic scale.

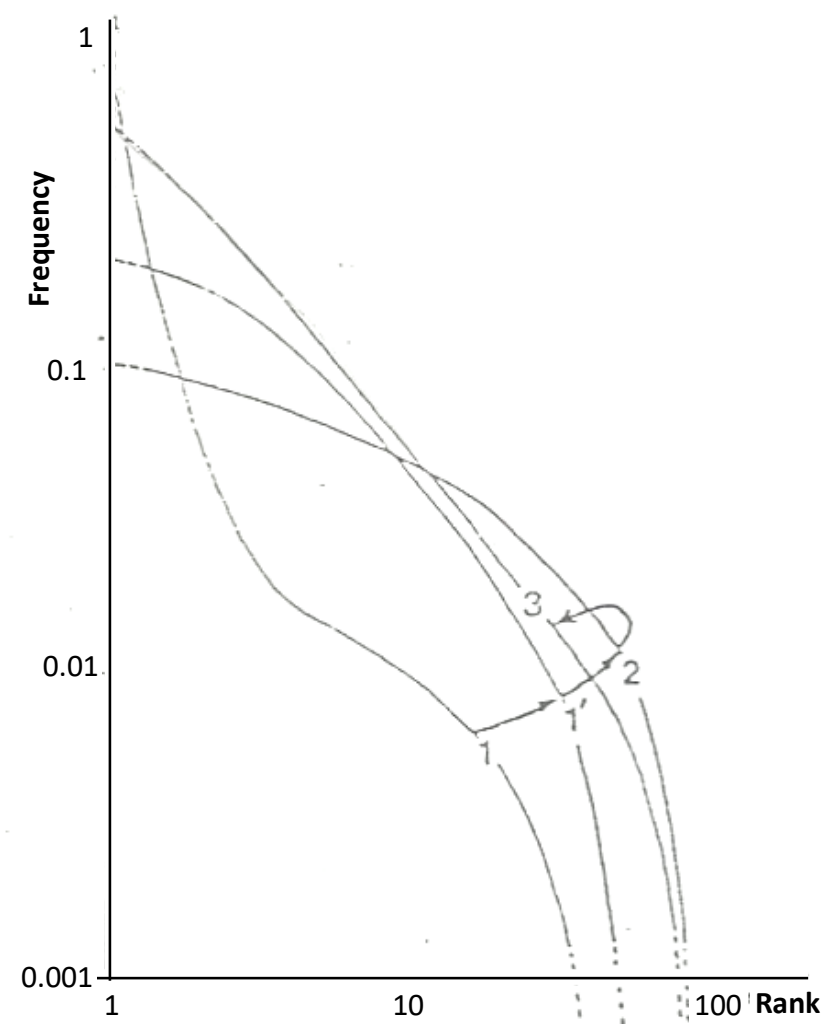

Figure 2. A graph model of phytoplankton succession (Frontier 1985)
Stadia 1 describes ecosystems that are still juvenile with pioneering communities, low biological productivity, unstable conditions, high competition among species, low diversity, and food web, as well as organisms in a state of stress. Stadia 2 illustrates the status of ecosystems with maximum diversity, high biological productivity, good conditions, low competition among species, decreased diversity, and complex food web. Stadia 3 is a picture of a climax ecosystem, decreased biological productivity, unstable conditions, competition among medium types, and complex food web.

The rate of change of phytoplankton can be determined through the summed difference index or SDI value which is symbolized by $\sigma \mathrm{s}$. SDI calculates phytoplankton succession, change, or rate of succession from time to time based on the temporal abundance of plankton data on Lake Siombak. SDI can be calculated using the following formula (Stander 1970):

$$
\sigma \mathrm{s}=\sum_{i}\left|d\left[b_{i}(t) / B(t)\right]\right| / d t
$$

Estimations along time intervals (William 1978) are formulated as follows:

$$
\sigma \mathrm{S}=\frac{\sum_{i}\left|\left[b_{i}\left(t_{1}\right) / B\left(t_{1}\right)\right]-\left[b_{i}\left(t_{2}\right) / B\left(t_{2}\right)\right]\right|}{t_{2}-t_{1}}
$$

Where: $\sigma \mathrm{s}$ : bi $\left(\mathrm{t}_{1}\right)$ success rate: an abundance of the species to- $\mathrm{i}$ at a time toward $1 \mathrm{~B}\left(\mathrm{t}_{1}\right)$ : total abundance at a time toward $1 \mathrm{bi}\left(\mathrm{t}_{2}\right)$ : an abundance of species toward $\mathrm{i}$ at a time toward $2 \mathrm{~B}\left(\mathrm{t}_{2}\right)$ : total abundance at a time toward $2 \mathrm{t}_{1}$ and $t_{2}$ : toward the 1 and 2 times.

\section{RESULTS AND DISCUSSION}

\section{The richness of plankton species}

Based on the results of plankton enumeration in Lake Siombak, there were 66 genera from 10 classes consisting of only 3 classes of phytoplankton and 7 classes of zooplankton. There were 54 genera of phytoplankton, while for zooplankton there were only 12 genera (Table 1 ). Based on several studies in coastal lakes, including the results of this study, the richness of plankton species in Lake Siombak is higher than that in the Grove Bay Lagoon (Nias, Indonesia), namely 28 genera (Hasudungan et al. 2008), a coastal lagoon in Baja California (México) there are as many as 47 genera (Gracia-Escobar et al. 2014), In Lake Ebony (Jakarta, Indonesia) there are 48 species (Pratiwi et al. 2018a) mainly in subtropic area; for example, there are only 32 species in Kamil Abdus, Lagoon, Turkey (Yilmaz et al. 2018). However, the richness of this species is much lower than that in Chilika Lake, India, which reaches 233-259 genera (Srichandan et al. 2015; Mukherjee et al. 2018), including in Yewa Lagoon which reaches 77 genera (Effiong and Inyang 2016). 
Table 1. Plankton genera found in Lake Siombak, Medan, North Sumatra, Indonesia

\begin{tabular}{llc}
\hline Phytoplankton & Chlorophyceae & Zooplankton \\
Bacillariophyceae & Binuclearia & Rhizopoda \\
Asterionella & Chaetopeltis & Astramoeba \\
Caloneis & Chlorella & Ciliata \\
Campylodiscus & Chlorosarcina & Paramecium \\
Chaetoceros & Closteriopsis & Nemata \\
Cocconeis & Closterium & Criconema \\
Coscinodiscus & Cosmarium & Dorylaimus \\
Cyclotella & Cylindrocapsa & Rotifera \\
Fragillaria & Cylindrocystis & Brachionus \\
Gyrosigma & Eremosphaera & Keratella \\
Melosira & Geminella & Mikrocodides \\
Navicula & Golenkinia & Cladocera \\
Neidium & Hyalotheca & Bosmina \\
Nitzschia & Oocardium & Copepoda \\
Peronia & Oocystis & Bryocamptus \\
Pinnularia & Palmodictyon & Cyclops \\
Stauroneis & Pediastrum & Diaptomus \\
Stephanodiscus & Phymatodocis & Ergasilidae \\
Surirella & Planktosphaeria & Ergasilus \\
Synedra & Prasiola & \\
Tabellaria & Scenedesmus & \\
Tetracyclus & Sirogonium & \\
Trigonium & Sphaeroplea & Spinoclosterium \\
Dinophyceae & Stigeoclonium & \\
Ceratium & Trochiscia & \\
Dinopodiella & Ulothrix & \\
Glenodinium & Zygnema & \\
Gonyaulax & & \\
& &
\end{tabular}
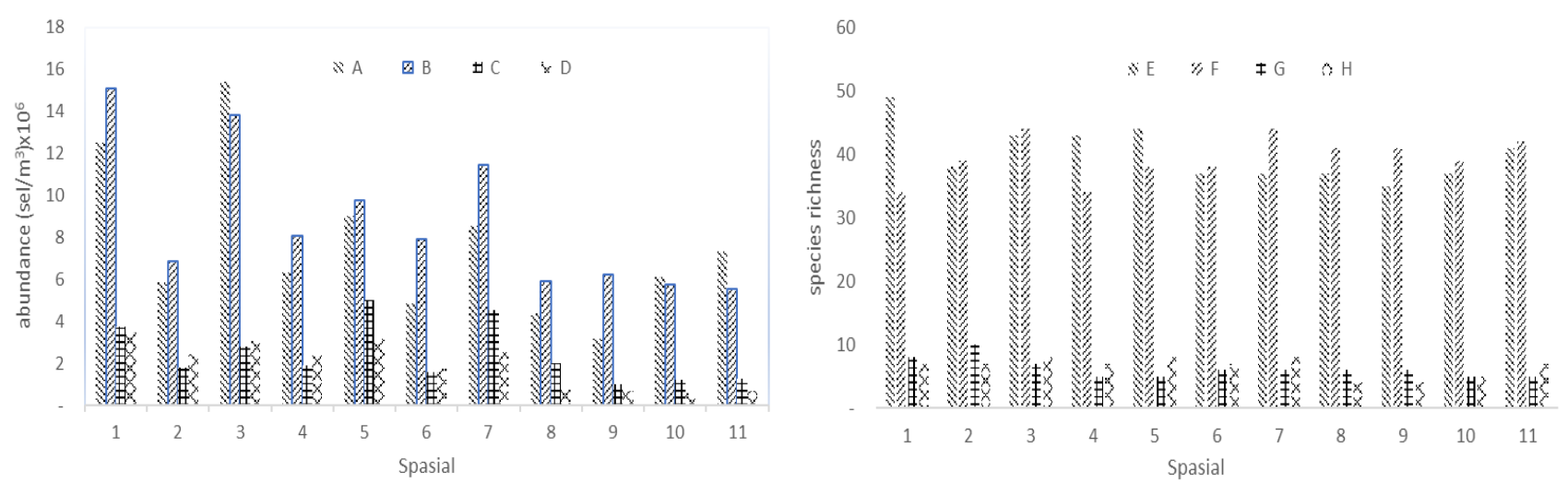

Figure 2. The abundance and richness of plankton spatially in Lake Siombak, Medan, North Sumatra, Indonesia. Note: A, E: phytoplankton at high tide; B, F: phytoplankton at low tide; C, G: zooplankton at low tide; D, H: zooplankton at high tide

\section{Spatial distribution}

Spatially, plankton is higher in lakes (station 1-8) than in rivers (station 9-11) at both low and high tides. The highest abundance of plankton at high tide reaches 18.61 million cells $/ \mathrm{m}^{3}$ at station 1, consisting of 15.09 million cells $/ \mathrm{m}^{3}$ phytoplankton $(81.11 \%)$ and 3.5161 million individual $/ \mathrm{m}^{3}(18.89 \%)$ zooplankton. At low tide, the highest abundance of plankton at station 3 reaches 18.20 million cells $/ \mathrm{m}^{3}$, consisting of 12.48 million cells $/ \mathrm{m}^{3}$ (76.91\%) phytoplankton and 3.74 million individual $/ \mathrm{m}^{3}$ (23.09\%) zooplankton. The lowest abundance of plankton at high tide at station 11 is 6.27 million cells $/ \mathrm{m}^{3}$, consisting of $88.72 \%$ phytoplankton and $11.28 \%$ zooplankton and at low tide, there are 4.20 million cells $/ \mathrm{m}^{3}$ at station 9, consisting of $75.75 \%$ phytoplankton and $24.25 \%$ zooplankton. Thus, spatially the average abundance of phytoplankton and zooplankton is higher at high tide than that at low tide. However, the proportion of zooplankton with phytoplankton is higher at low tide (an average of $24.37 \%$ ) than that at high tide (an average of $17.24 \%$ ).

Plankton mostly found is from the class of Chlorophyceae, that is, as many as 28 genera, and then it is 
followed by the class of Bacillariophyceae found as many as 22 genera (Table 1). The class of Chlorophyceae found reaches $69-87 \%$ (Figures 3 and 5). The number of genera found from those classes is because Chlorophyceae has a high tolerance and generally they are lake plankton composers. Based on some research, Chlorophyceae class can be found mostly in lake waters (Giripunje et al. 2013; Muhtadi et al. 2015; Öterler 2018), including in a coastal or brackish lake (Nassar and Gharib 2014; Pratiwi et al. 2018a), estuaries (Dewi et al. 2019; Yang et al. 2019). However, Obolewski et al. (2018) and Cardoso et al. (2019) found that plankton in a coastal lake which lacks nutrient is dominated by Cyanobakteri reaching until $80 \%$. Nonetheless, in coastal lakes that tend to be saltier phytoplankton is generally dominated by Bacillariopyceae (Onyema 2008; Srichandan et al. 2015; Mukherjee et al. 2018; Yilmaz et al. 2018; Cutrim et al. 2019) and Dinophyceae (Hasudungan et al. 2008), including in coastal waters (Ajibare et al. 2019). In very dynamic waters such as an estuary, Yang et al. (2019) found varied plankton dynamics in which the Chlorophyta and the Bacillariophyta were high during spring, and Cyanophyta was high during summer in Estuary Reservoir in the Yangtze River, China.

\section{Temporal distribution}

Temporally, the highest plankton is found in April when at high tides it reaches 20.63 million cells $/ \mathrm{m}^{3}$ consisting of 17.01 million cells $/ \mathrm{m}^{3}$ phytoplankton $(82.45 \%)$ and 3.62 individual $/ \mathrm{m}^{3}$ zooplankton (17.55\%). At low tides, the highest abundance happens in March which reaches 14.10 cells $/ \mathrm{m}^{3}$ consisting of 8.03 cells $/ \mathrm{m}^{3}$ phytoplankton $(57.01 \%)$ and 6.06 individual $/ \mathrm{m}^{3}$ zooplankton $(42.99 \%)$, while the lowest abundance happens in November at high tides and in May at low tides. The lowest abundance reaches 6.61 cells/L (76.09\% Phyto and $23.91 \%$ zoo) respectively and 4.80 cells/L $(92.78 \%$ Phyto and $7.22 \%$ zoo). Like spatially, temporally the average abundance of phytoplankton and zooplankton is higher during high tides than that during low tides. However, the proportion of zooplankton with phytoplankton is higher during low tides (an average of $24.16 \%$ ) than that during high tides (an average of $20.13 \%)$.

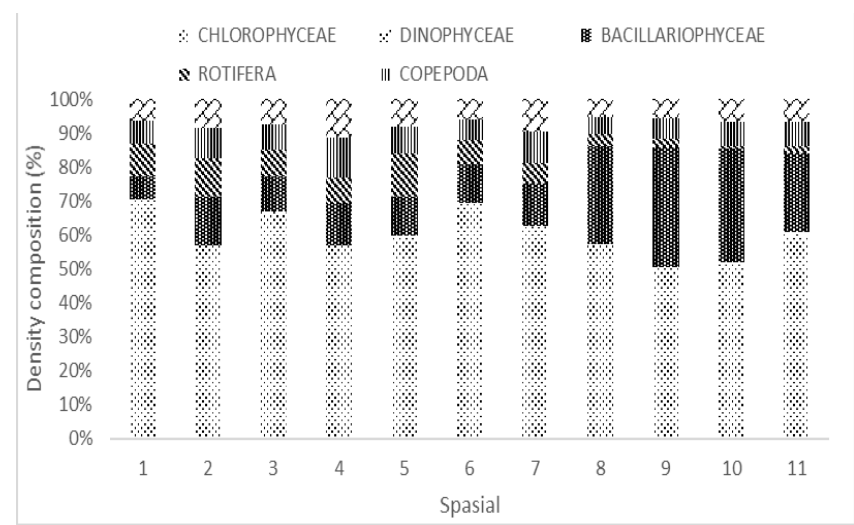

A

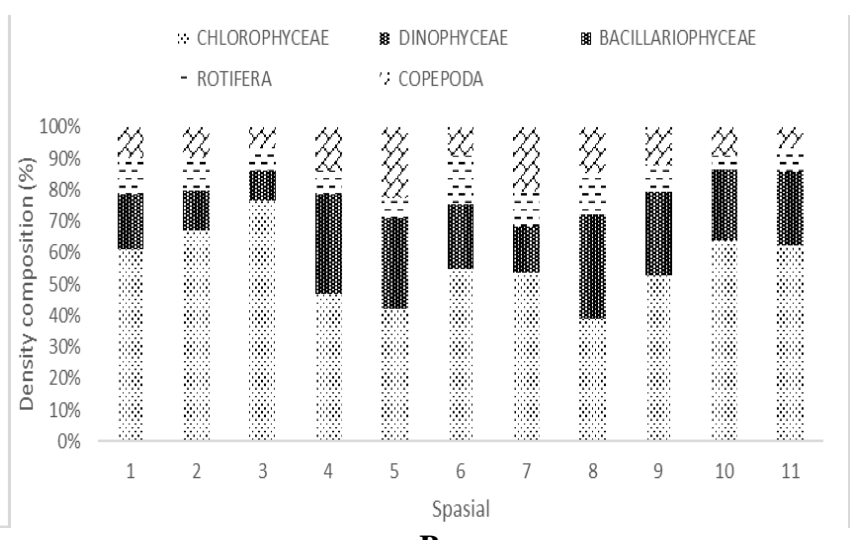

$\mathbf{B}$

Figure 3. Composition of plankton abundance spatially in Lake Siombak, Medan, North Sumatra, Indonesia. A. High tide, B. Low tide
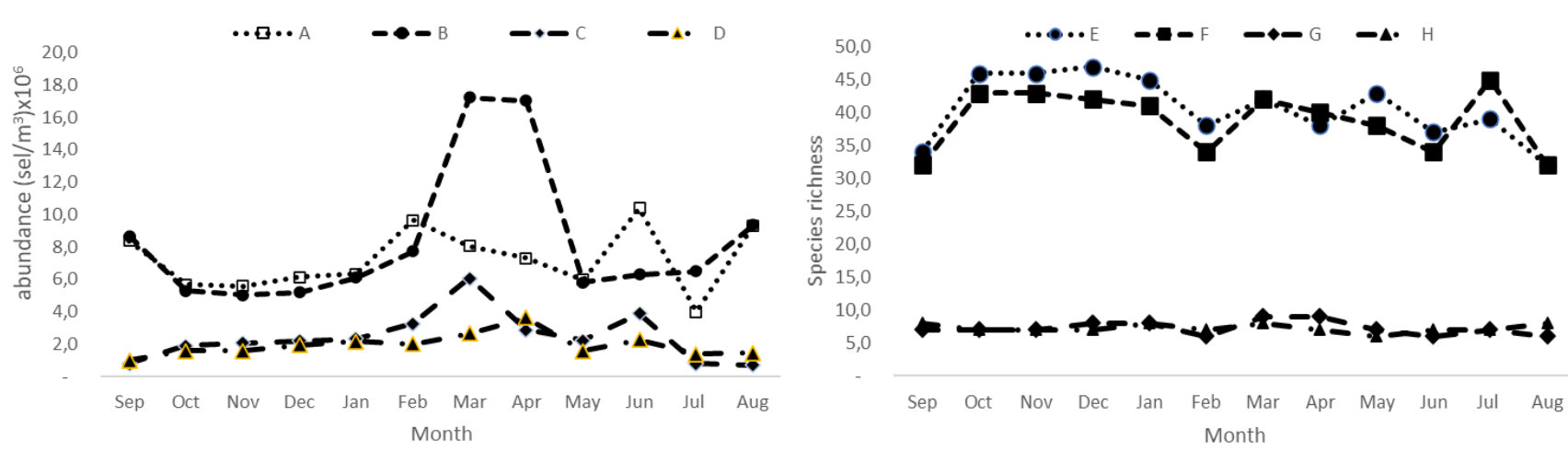

Figure 4. Temporal abundance and richness of plankton in Lake Siombak, Medan, North Sumatra, Indonesia. Note: A, E: Phytoplankton at high tide; B, F: Phytoplankton at low tide; C, G: Zooplankton at low tide; D, H: Zooplankton at high tide 


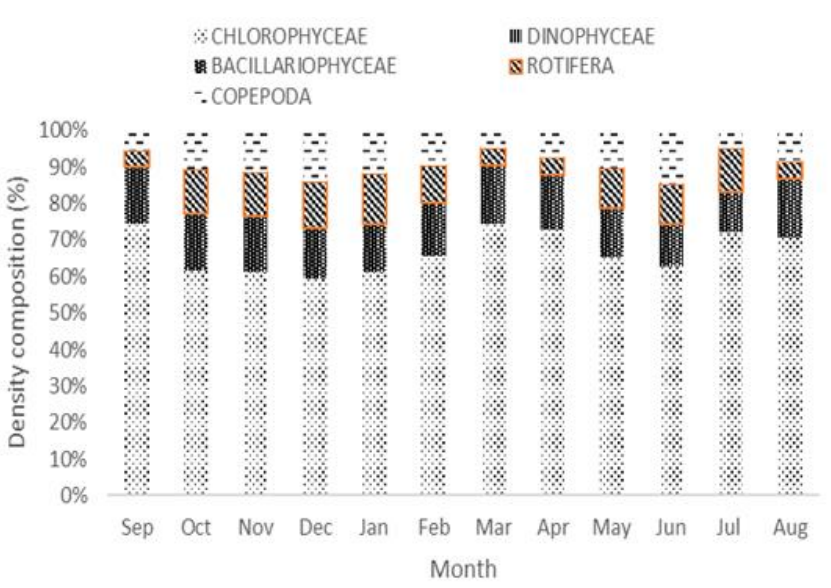

A

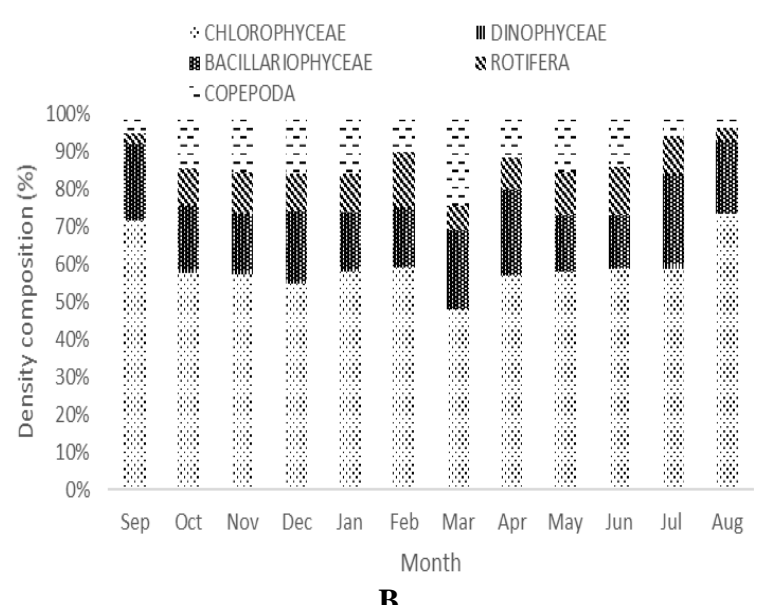

B

Figure 5. The composition of temporal plankton abundance in Lake Siombak, Medan, North Sumatra, Indonesia. A. High tide, B. Low tide

\section{Diversity index}

Based on the analysis of the plankton community structure at each station, this shows variations both spatially and temporally (Table 2-3). This is consistent with spatial and temporal variations in the abundance and composition of plankton species in Lake Siombak (Figure 2-4). Although the abundance of chopped phytoplankton is highest at stations 1 and 3 (high and low tides), high diversity is found at stations 4 and 5 (low tides) and 8 and 9 (high tides). This is because the proportion of species is more evenly distributed at stations 4 and 5 (low tides) and 8 and 9 (high tides). This was explained by Muhtadi et al. $(2015 ; 2017 b)$ that the proportion of species in a community is very influential on the diversity index compared to its abundance.

Likewise temporarily, during dry season phytoplankton is significantly abundant, but high diversity is precisely in the rainy season. This is because the proportion of species in the rainy season is more even than that in the dry season.
Besides, it can be seen in Figure 2 on the right that the number of species found in the rainy season is more than that in the dry season. Based on Table 2-3, it can be said that diversity is higher at low tide than that at high tide. In this case, it is inversely proportional to the high abundance at high tide compared to that at low tide.

Based on this diversity index, it shows that Lake Siombak is considered to have high diversity with an $\mathrm{H}^{\text {' }}$ value of 3.27. Pratiwi et al. (2018a) state that it is with a very high abundance in Lake Ebony with a value of $\mathrm{H}^{\prime}$ 1.32-2.08, including other coastal lakes in Yewa Lagoon (Nigeria) ranging from 1.09-1.95 (Effiong and Inyang, 2016). The high diversity in Lake Siombak causes the absence of dominant genera. This can be seen from the low dominance index. The dominance index value in Lake Siombak only ranges between $0.07-0.22(<0.3)$. This is also supported by a fairly high uniformity value ranging from 0.67-0.86 (> 0.5). Odum and Barrett (2005) states that the value of dominance will be below if it has high diversity.

Table 2. Diversity index of plankton spatially

\begin{tabular}{|c|c|c|c|c|c|c|c|c|c|c|c|c|}
\hline \multirow{2}{*}{ Index } & \multirow{2}{*}{ Tide } & \multicolumn{11}{|c|}{ Locations } \\
\hline & & 1 & 2 & 3 & 4 & 5 & 6 & 7 & 8 & 9 & 10 & 11 \\
\hline \multicolumn{13}{|l|}{ Phytoplankton } \\
\hline \multirow[t]{2}{*}{ Diversity index $\left(\mathrm{H}^{\prime}\right)$} & HT & 2.37 & 2.58 & 2.59 & 2.13 & 2.41 & 2.42 & 2.44 & 2.94 & 2.94 & 2.92 & 2.59 \\
\hline & LT & 2.88 & 2.52 & 2.34 & 3.24 & 3.27 & 2.62 & 2.71 & 2.93 & 2.75 & 2.92 & 2.50 \\
\hline \multirow[t]{2}{*}{ Evenness index (E) } & HT & 0.67 & 0.70 & 0.68 & 0.61 & 0.66 & 0.67 & 0.65 & 0.79 & 0.79 & 0.80 & 0.69 \\
\hline & LT & 0.74 & 0.69 & 0.62 & 0.86 & 0.86 & 0.73 & 0.75 & 0.81 & 0.77 & 0.81 & 0.67 \\
\hline \multirow[t]{2}{*}{ Dominance index (C) } & HT & 0.17 & 0.14 & 0.16 & 0.27 & 0.19 & 0.17 & 0.19 & 0.11 & 0.11 & 0.11 & 0.19 \\
\hline & LT & 0.11 & 0.18 & 0.19 & 0.06 & 0.05 & 0.17 & 0.13 & 0.09 & 0.12 & 0.07 & 0.22 \\
\hline \multicolumn{13}{|l|}{ Zooplankton } \\
\hline \multirow[t]{2}{*}{ Diversity index (H') } & HT & 1.26 & 1.24 & 1.21 & 1.21 & 1.20 & 1.42 & 1.19 & 1.19 & 1.05 & 0.93 & 1.27 \\
\hline & LT & 1.33 & 1.50 & 1.32 & 1.11 & 1.34 & 1.12 & 1.32 & 1.30 & 1.26 & 1.25 & 1.06 \\
\hline \multirow{2}{*}{ Evenness index (E) } & HT & 0.60 & 0.59 & 0.55 & 0.58 & 0.55 & 0.68 & 0.54 & 0.74 & 0.65 & 0.52 & 0.61 \\
\hline & LT & 0.60 & 0.62 & 0.63 & 0.62 & 0.75 & 0.58 & 0.68 & 0.67 & 0.65 & 0.70 & 0.59 \\
\hline \multirow[t]{2}{*}{ Dominance index (C) } & HT & 0.36 & 0.30 & 0.36 & 0.36 & 0.39 & 0.25 & 0.39 & 0.21 & 0.33 & 0.47 & 0.31 \\
\hline & LT & 0.35 & 0.27 & 0.33 & 0.39 & 0.38 & 0.39 & 0.36 & 0.30 & 0.26 & 0.25 & 0.39 \\
\hline
\end{tabular}

Note: HT: Hight tide; LT: Low Tide 
Table 3. Diversity index of plankton temporally

\begin{tabular}{|c|c|c|c|c|c|c|c|c|c|c|c|c|c|}
\hline \multirow{2}{*}{ Index } & \multirow{2}{*}{ Tide } & \multicolumn{12}{|c|}{ Month } \\
\hline & & Sep & Oct & Nov & Dec & Jan & Feb & Mar & Apr & May & Jun & Jul & Aug \\
\hline \multicolumn{14}{|l|}{ Phytoplankton } \\
\hline \multirow[t]{2}{*}{ Diversity index $\left(\mathrm{H}^{\prime}\right)$} & HT & 1.82 & 2.41 & 2.47 & 2.48 & 2.42 & 2.51 & 2.07 & 2.03 & 2.35 & 2.42 & 2.36 & 1.83 \\
\hline & LT & 1.86 & 2.82 & 2.91 & 2.91 & 2.87 & 2.83 & 2.85 & 2.71 & 2.82 & 2.76 & 2.77 & 1.79 \\
\hline \multirow[t]{2}{*}{ Evenness index (E) } & HT & 0.52 & 0.64 & 0.66 & 0.66 & 0.65 & 0.71 & 0.55 & 0.55 & 0.65 & 0.69 & 0.62 & 0.53 \\
\hline & $\mathrm{LT}$ & 0.53 & 0.74 & 0.76 & 0.76 & 0.75 & 0.78 & 0.76 & 0.74 & 0.75 & 0.76 & 0.76 & 0.52 \\
\hline \multirow[t]{2}{*}{ Dominance index $(\mathrm{C})$} & HT & 0.36 & 0.23 & 0.22 & 0.22 & 0.21 & 0.14 & 0.32 & 0.33 & 0.22 & 0.15 & 0.21 & 0.35 \\
\hline & $\mathrm{LT}$ & 0.35 & 0.12 & 0.11 & 0.11 & 0.12 & 0.09 & 0.13 & 0.16 & 0.11 & 0.10 & 0.12 & 0.37 \\
\hline \multicolumn{14}{|l|}{ Zooplankton } \\
\hline \multirow[t]{2}{*}{ Diversity index $\left(\mathrm{H}^{\prime}\right)$} & HT & 1.29 & 0.99 & 0.98 & 0.94 & 0.99 & 1.15 & 1.23 & 1.04 & 0.94 & 1.10 & 1.02 & 1.12 \\
\hline & $\mathrm{LT}$ & 1.13 & 1.10 & 1.08 & 1.16 & 1.12 & 1.10 & 1.04 & 1.08 & 1.12 & 1.05 & 1.05 & 1.08 \\
\hline \multirow[t]{2}{*}{ Evenness index (E) } & HT & 0.62 & 0.51 & 0.51 & 0.48 & 0.48 & 0.59 & 0.59 & 0.54 & 0.53 & 0.56 & 0.52 & 0.54 \\
\hline & $\mathrm{LT}$ & 0.58 & 0.56 & 0.55 & 0.56 & 0.54 & 0.61 & 0.47 & 0.49 & 0.58 & 0.59 & 0.54 & 0.60 \\
\hline \multirow[t]{2}{*}{ Dominance index $(\mathrm{C})$} & HT & 0.34 & 0.44 & 0.44 & 0.45 & 0.44 & 0.39 & 0.37 & 0.43 & 0.45 & 0.40 & 0.45 & 0.41 \\
\hline & LT & 0.39 & 0.42 & 0.42 & 0.40 & 0.41 & 0.41 & 0.48 & 0.42 & 0.40 & 0.41 & 0.44 & 0.40 \\
\hline
\end{tabular}

Note: HT: Hight tide; LT: Low Tide

Meanwhile zooplankton diversity in Lake Siombak ranges between 0.93-1.42 at high tides and $1.06-1.50$ at low tides. Just like phytoplankton, zooplankton diversity is higher at low tide than that at high tide. Zooplankton diversity is lower than phytoplankton due to the high abundance and richness of phytoplankton species (a total of 54 genera) compared to zooplankton (12 genera).

\section{The relationship of environmental conditions with the plankton community}

The results of multiple linear regression analysis show that both spatial and temporal environmental conditions that affect the abundance of phytoplankton and zooplankton during high tides and low tides are not the same. Spatially, the tidal abundance of phytoplankton is influenced by the value of TSS and phosphate and zooplankton abundance ( $\mathrm{R}$ square value reaching 0.95 with a correlation value of 0.98 ). This shows that the abundance of phytoplankton is highly dependent on the parameters of TSS, water transparency, phosphate, and abundance of zooplankton, in which the three parameters explain $95 \%$ of the actual situation. This value strongly illustrates the true condition with an $\mathrm{R}$ square value above $85 \%$. Meanwhile, at low tide, the abundance of phytoplankton was affected by TSS, water transparency, BOD, and silica with an R square value of 0.97 and a correlation value of 0.95 . Waya et al. (2017) found that transparency significant effect on the abundance of plankton in the lake Lake Victoria, Tanzania. Furthermore, Takarina et al. (2019) also found a strong relationship between phytoplankton and the intensity of sunlight and nutrients in the coastal waters of Banten. Thus, both the tides and ebb abundance of phytoplankton are influenced by the presence of sunlight and nutrients. The results of Flöder et al. (2002) and Charalampous et al. (2018) found that sunlight entering the waters greatly affected the phytoplankton community. Furthermore, according to Wetzel (2001) and Odum and Barrett (2005), the availability of nutrients in waters is a limiting factor for the growth of autotrophic organisms. Furthermore, Filippino et al. (2011); Qurban et al. (2017), the most influential nutrients on the growth and development of plankton are nitrogen $\left(\mathrm{NO}_{3}\right)$ and phosphorus $\left(\mathrm{PO}_{4}\right)$, including total nitrogen and silicates in estuarine exposure (Wu and Chou 2003; Örnólfsdóttir et al. 2004; BarreraAlba and Moser 2016).

Spatially, the abundance of zooplankton at high tide is influenced by TSS, salinity, and abundance of zooplankton ( $\mathrm{R}$ Square value reaches 0.91 with a correlation value of 0.95). At low tide, the abundance of zooplankton is affected by salinity, phytoplankton, and DO ( $\mathrm{R}$ square values reach 0.80 and correlation values 0.90 ). In contrast to phytoplankton that requires sunlight and nutrients for growth, zooplankton requires phytoplankton as a food source and salinity conditions where the waters of the wave lake have fluctuations in salinity both spatially and temporally. The results of Almeida et al. (2012) shows that salinity impacts the horizontal distribution of zooplankton in an estuarine lagoon in Northeast Brazil, including in the Northern Kerala estuary, India (Jeyaraj et al. 2014) and the waters of the Bonang estuary, Demak (Yudhatama et al. 2019) and waters Banten Pandeglang beach (Takarina et al. 2019). Related to phytoplankton as a food source of zooplankton, Mialet et al. (2011) obtained the results of a study that showed that the abundance of zooplankton in water was greatly affected by the abundance of phytoplankton in the fair. The results of multiple regression analyzes of phytoplankton abundance with environmental conditions at spatial tides and ebbs are presented in Tables 4 and 5 .

Temporally, the abundance of phytoplankton is affected by the salinity and conductivity at both high and low tides as well as discharge at high tides and COD and turbidity at low tides. Both coefficients of determination ( $\mathrm{R}$ Square) are also very high, reaching 0.96 at high tide which means the parameters of salinity, conductivity, and discharge describe the actual conditions of $96 \%$ with a strong 
correlation value reaching 0.98 . At low tide, the effect of conductivity, turbidity, and COD is lower than the tide that is equal to 0.87 with $\mathrm{R}$ Square of 0.76. Meanwhile, zooplankton abundance at high tide was influenced by TSS, salinity, discharge, and the abundance of phytoplankton with $\mathrm{R}$ Square reached 0.85 and the correlation value was 0.92 . At low tide the abundance of zooplankton is influenced by many factors namely salinity, DO, TDS, TSS, conductivity, turbidity, BOD, and COD with R Square value and a very strong correlation value of 0.99 .

Temporally, plankton regression analysis with water quality, shows that salinity has a strong influence on the presence of phytoplankton and zooplankton. Even zooplankton, both spatially and temporally shows that salinity has a strong influence on the abundance of zooplankton. This can be seen in Tables 6 and 7 that both the spatial and temporal parameters of salinity consistently exert influence on the abundance of zooplankton. This is according to the research of Almeida et al. (2012), Jeyaraj et al. (2014), and Takarina et al. (2019) which shows the effect of salinity on the distribution and abundance of zooplankton in waters.

In contrast to spatial, temporally shows that there is an influence of incoming water discharge on the abundance of phytoplankton and zooplankton in the lake waves. This is related to the mass of water that enters the lake which can carry phytoplankton from the sea or river. Pereira et al. (2005) explains that current and discharge can affect plankton abundance in estuary waters.

Table 4. Spatially, multiple regression analysis of phytoplankton abundance with environmental parameters at high tide

\begin{tabular}{|c|c|c|c|c|c|}
\hline \multirow{2}{*}{ Parameters } & \multicolumn{2}{|c|}{ High tide } & \multirow{2}{*}{ Parameters } & \multicolumn{2}{|c|}{ Low tide } \\
\hline & Coefficients & P-value & & Coefficients & Coefficients \\
\hline Intercept & $2,788,230.6463$ & 0.0304 & Intercept & $-976,556.8031$ & 0.7364 \\
\hline TSS & $-66,918.6746$ & 0.0344 & TSS & $243,606.4718$ & 0.0145 \\
\hline Water transparency & $173,344.8516$ & 0.0286 & Water transparency & $221,250.8650$ & 0.0006 \\
\hline Phosphate & $1,517,923.4061$ & 0.0204 & BOD & $-172,526.3555$ & 0.0077 \\
\hline Zooplankton & 2.9252 & 0.0003 & Silicate & $371,654.0463$ & 0.0051 \\
\hline $\mathrm{F}$ & 29.4815 & & $\mathrm{~F}$ & 41.3886 & \\
\hline Significance F & 0.0004 & & Significance F & 0.0002 & \\
\hline
\end{tabular}

Table 5. Spatially, multiple regression analysis of zooplankton abundance with environmental parameters at low tide

\begin{tabular}{|c|c|c|c|c|c|}
\hline \multirow{2}{*}{ Parameters } & \multicolumn{2}{|c|}{ High tide } & \multirow{2}{*}{ Parameters } & \multicolumn{2}{|c|}{ Low tide } \\
\hline & Coefficients & P-value & & Coefficients & Coefficients \\
\hline Intercept & $1,648,632.2739$ & 0.0792 & Intercept & $-6,248,970.3718$ & 0.0120 \\
\hline TSS & $18,585.8308$ & 0.0138 & Salinity & $484,763.6341$ & 0.0066 \\
\hline Salinity & $-297,326.3256$ & 0.0136 & Phytoplankton & 0.2689 & 0.0047 \\
\hline Phytoplankton & 0.2088 & 0.0018 & DO & $1,168,982.7483$ & 0.0359 \\
\hline $\mathrm{F}$ & 8.2535 & & $\mathrm{~F}$ & 9.5497 & \\
\hline Significance F & 0.0078 & & Significance F & 0.0072 & \\
\hline
\end{tabular}

Table 6. Temporally, multiple regression analysis of phytoplankton abundance with environmental parameters at high tide

\begin{tabular}{|c|c|c|c|c|c|}
\hline \multirow{2}{*}{ Parameters } & \multicolumn{2}{|c|}{ High tide } & \multirow{2}{*}{ Parameters } & \multicolumn{2}{|c|}{ Low tide } \\
\hline & Coefficients & P-value & & Coefficients & P-value \\
\hline Intercept & $-1,704,315.8045$ & 0.1357 & Intercept & $10,323,813.9634$ & 0.0000 \\
\hline Salinity & $877,314.8664$ & 0.0003 & Conductivity & $-467,011.9972$ & 0.0112 \\
\hline Conductivity & $444,179.8152$ & 0.0008 & Turbidity & $-2,995.9456$ & 0.0019 \\
\hline Debit & $-48,908.2410$ & 0.0225 & $\mathrm{COD}$ & $6,954.6093$ & 0.0042 \\
\hline $\mathrm{F}$ & 74.0699 & & $\mathrm{~F}$ & 18.0072 & \\
\hline Significance F & 0.000004 & & Significance F & 0.0011 & \\
\hline
\end{tabular}


Table 7. Temporally, multiple regression analysis of zooplankton abundance with environmental parameters at low tide

\begin{tabular}{|c|c|c|c|c|c|}
\hline \multirow{2}{*}{ Parameters } & \multicolumn{2}{|c|}{ High tide } & \multirow{2}{*}{ Parameters } & \multicolumn{2}{|c|}{ Low tide } \\
\hline & Coefficients & P-value & & Coefficients & Coefficients \\
\hline Intercept & $279,784.0119$ & 0.5140 & Intercept & $-9,165,839.7730$ & 0.0156 \\
\hline TSS & $11,215.0259$ & 0.0457 & Salinity & $-380,425.3136$ & 0.0315 \\
\hline Debit & $30,325.8815$ & 0.0052 & DO & $754,499.8508$ & 0.0143 \\
\hline Phytoplankton & 0.2866 & 0.0117 & TDS & -479.7693 & 0.0309 \\
\hline Salinity & $-287,488.0486$ & & TSS & $98,764.3416$ & 0.0048 \\
\hline & & & Conductivity & $1,558,099.8012$ & 0.0099 \\
\hline & & & Turbidity & $2,811.3140$ & 0.0147 \\
\hline & & & $\mathrm{BOD}$ & $30,806.2025$ & 0.0112 \\
\hline & & & COD & $-13,687.3707$ & 0.0115 \\
\hline $\mathrm{F}$ & 9.5835 & & $\mathrm{~F}$ & 50.6089 & \\
\hline Significance F & 0.0057 & & Significance F & 0.0041 & \\
\hline
\end{tabular}
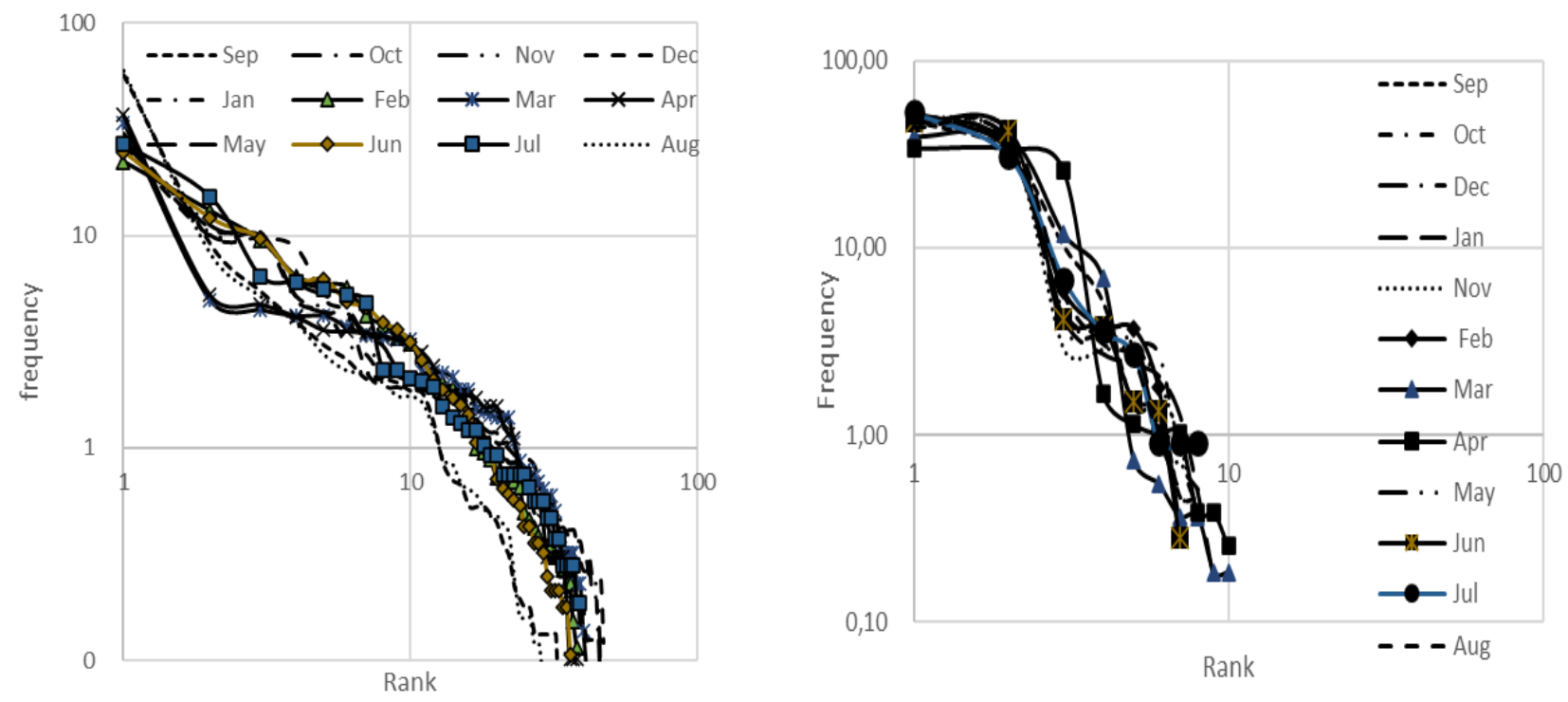

Figure 8. Frontier graph of phytoplankton (left) and zooplankton (right) succession

\section{Plankton succession}

Based on the plankton Frontier succession graph, it shows that Lake Siombak is included in stage 1 and stage 2, as shown in Figure 8. Stadia 1 in Frontier succession is found in phytoplankton during the rainy season (AugustSeptember) and the peak of the dry season (March-April). Stadia 1 is characterized by unstable water conditions with high type of competition (Frontier 1985). Lake Siombak is a very dynamic lake whose waters condition changes according to daily tidal dynamics. Thus, the characteristics of the waters change based on the tidal cycle, especially salinity and other organic matter (Muhtadi et al. 2017). In the rainy season (phytoplankton) and the succession of zooplankton include stadia 2 which is characterized by more stable water conditions with maximum diversity, high biological productivity, good conditions, low competition among species, and decreased diversity (Frontier 1985).
The change of stadia 1 to Stadia 2 on the phytoplankton succession chart shows differences in diversity, diversity, and productivity from phytoplankton. This can be seen from the low succession rate in the rainy season (Sept-Jan) ranging between $0.49-0.55$ and high in the dry season (FebJun) which is 1.87-4.26, as shown in Figure 9. Furthermore, the succession rate is then associated with SIMI (Stander's similarity index) which indicates the similarity among research times. It can be seen in the graph that when the succession rate at $\mathrm{tn}$ and $\mathrm{tn}+1$ approaches maximum (value 1) (except the dry season), then the similarity value of the presence of plankton between the two times is high close to 1 . When the lowest succession rate value is 0.49 , it appears that the value SIMI reaches 4 . When the highest succession rate value is 4.26 , the SIMI value approaches 0 , which is 0.13 . 


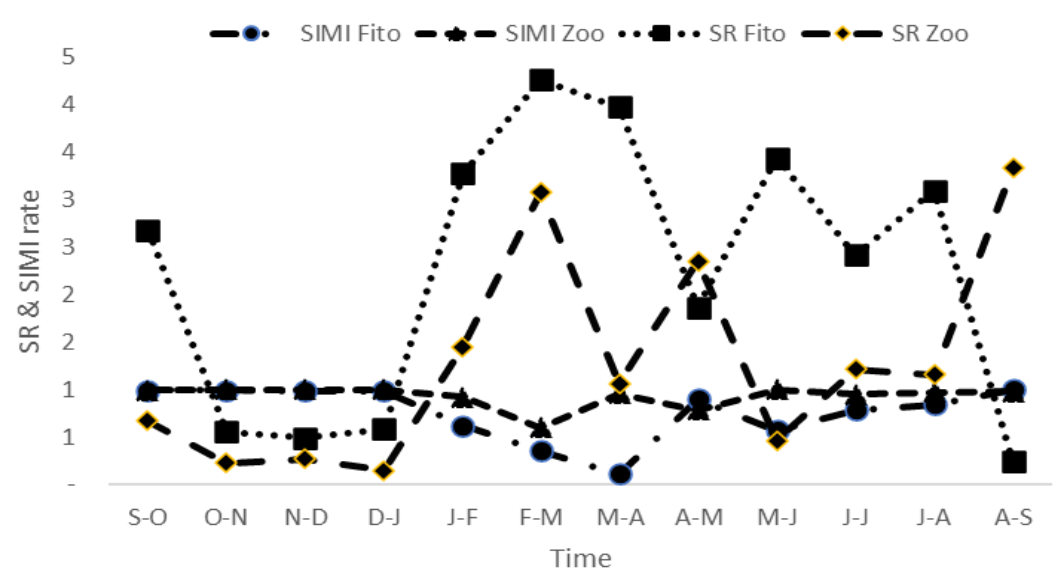

Figure 9. SIMI chart and succession rate of plankton in Lake Siombak, Medan, North Sumatra, Indonesia

Based on the above explanation, it shows that if the succession rate is high, then the SIMI value will be low, and vice versa. A SIMI value close to 1 indicates that the similarity is in a maximum state with a succession rate of 0.49 , indicating that the motion or change between th and tn +1 is small. Conversely, the SIMI value is close to 0 , indicating that similarity is in a minimum state with a high succession rate up to 4.26 which indicates that the movement of changes between th and tn +1 is very large. When viewed from the abundance and number of types of phytoplankton in th and $t n+1$, the value is quite different.

\section{Discussion}

The abundance of plankton in Lake Siombak is still lower than in other brackish/coastal lakes in Indonesia, where Hasudungan et al. (2008) found a high abundance up to 33 million cells $/ \mathrm{m}^{3}$ in the Grove Bay Lagoon, Nias; Pratiwi et al. (2018a) even found the abundance of phytoplankton alone up to 1800 million cells $/ \mathrm{m}^{3}$ in Lake Ebony, Jakarta. However, the abundance of plankton in Lake Siombak is still lower than that in Lake Chilika (India) which only reaches 2.3 million cells $/ \mathrm{m}^{3}$ (Srichandan et al. 2015). This very significant difference is caused by various things including the availability of nutrients in the form of NP ratio (Conan et al. 2017; Gamito et al. 2019; Gophen 2019; Yang et al. 2019), including the availability of ammonia (Pratiwi et al. 2018a), temperature and salinity (Srichandan et al. 2015; Pratiwi et al. 2018a; Yang et al. 2019), and the availability of light (Yang et al. 2019). Even Obolewski et al. (2018) and Gophen (2019) state that the residence time is the main key in controlling the dynamics of phytoplankton, while the dynamics of zooplankton itself is strongly influenced by temperature, salinity, and $\mathrm{pH}$ (Paturej et al. 2017)

Geminella (phytoplankton) and Diaptomus (zooplankton) are plankton that is always found at each station with an average abundance of 2,626,137.74 million cells $/ \mathrm{m} 3 \quad(25.15 \%)$ and $917,597.80$ million cells $/ \mathrm{m}^{3}$ $(8.82 \%)$. Other genera that are always found and abundant in the wave lake are Trochiscia and Planktosphaeria from the phytoplankton group and Brachionus and Cyclops from zooplankton. In the saltier coastal lakes (salinity> $25 \mathrm{ppt}$ ),
Peridinium and Chaetoceros (Phytoplankton) and Cyclops are very dominant in the Grove Bay (Hasudungan et al. 2008), while in the tastier coastal lakes (salinity $<5$ ppt), Merismopedia sp. and Cyclotella sp. are more dominant in Lake Ebony (Pratiwi et al. 2018a). In this lake, the range of salinity ranges from 5-15 ppt (Muhtadi et al. 2016).

Overall during both low and high tides the abundance of phytoplankton was higher than that of zooplankton. Phytoplankton abundance reaches $64.35 \%-90.77 \%$ with an average of $79.19 \%$ compared to zooplankton abundance. The amount of zooplankton found was on average $20.81 \%$ of the total plankton that was chopped. This is not only because the collection was carried out during the day but also the depth has taken was in the zone of high sunlight penetration. Zooplanktons that have high abundance are Copepod (Diaptomus and Cyclops), Rotifer (Brachionus), and Cladocera (Bosmina). These three groups were also found in all observation stations. This is because these types of zooplankton have a wide distribution in the aquatic environment and can live in various types of water (Mirón et al. 2014; Sahu et al. 2016; Gamito et al. 2019).

Temporally it shows that plankton abundance is higher in the rainy season (Feb-Aug, excluding May) than in the dry season (Sep-Jan, and May) (Figure 4). The same thing was obtained by Pratiwi et al. (2018a) where the highest abundance of phytoplankton is in the dry season as obtained by Pratiwi et al. (2018a). Although the nutrient is lower in the dry season, the plankton abundance is high at that time. This shows that the nutrient is not a limiting factor in Lake Siombak because of its high availability in water.

\section{REFERENCES}

Adesalu TA, Nwankwo DI. 2011. The successional pattern of phytoplankton $(>55 \mu \mathrm{m})$ in Lekki Lagoon, Nigeria. Rev Biol Trop 60 (1): 143-155.

Ajibare AO, Ayeku PO, Akinola JO, Adewale AH. 2019. Plankton composition in relation to water quality in the coastal waters of Nigeria. Asian J Fish Aquat Res 5 (2): 1-9. DOI: 10.9734/ajfar/2019/v5i230070. 
Almeida LR, Costa IS, Eskinazi-Sant'Anna EM. 2012. Composition and abundance of zooplankton community of an impacted estuarine lagoon in Northeast Brazil. Braz J Biol 72 (1): 13-24. DOI: 10.1590/S1519-69842012000100002.

Barrera-Alba JJ, Moser GAO. 2016. Short-term response of phytoplankton community to over-enrichment of nutrients in a wellpreserved sub-tropical estuary. Braz J Oceanogr 64 (2): 191-196. DOI: $10.1590 / \mathrm{S} 1679-87592016115406402$.

Bellinger EG, Sigee DC. 2010. Freshwater Algae: Identification and Use as Bioindicators. Wiley-Blackwell, Chichester, United Kingdom.

Bueno-Pardo J, García-Seoane E, Sousa AI, Coelho JP, Morgado M, Frankenbach S, Ezequiel J, Vaz N, Quintino V, Rodrigues AM, Leandro S, Luis A, Serôdio J, Cunha MR, Calado AJ, Lillebø A Rebelo JE. 2018. Trophic web structure and ecosystem attributes of temperate coastal lagoon (Ria de Aveiro, Portugal). Ecol Model 378 13-25. DOI: 10.1016/j.ecolmodel.2018.03.009.

Cardoso L de S, de Faria DM, Crossetti LO, da Motta MD. 2019. Phytoplankton, periphyton, and zooplankton patterns in the pelagic and littoral regions of a large subtropical shallow lake. Hydrobiol 831 (1): 119-132. DOI: 10.1007/s10750-018-3729-2.

Charalampous E, Matthiessen B, Sommer U. 2018. Light effects on phytoplankton morphometric traits influence nutrient utilization ability. J Plankton Res 40 (5): 568-579. DOI: 10.1093/plankt/fby037

Chen N, Liu L, Qiao D, Li Y, Lv Y. 2016. Seasonal succession patterns of plankton in eutrophic rivers on plains. Ann Limnol Int J Lim. 52 (2016): 217-233. DOI: 10.1051/limn/2016007.

Conan P, Pujo-Pay M, Agab M, Calva-Benítez L, Chifflet S, Douillet P, Dussud C, Fichez R, Grenz C, Gutierrez MF, Origel-Moreno M, Rodríguez-Blanco A, Sauret C, Severin T, Tedetti M, Alvarado RT, Ghiglione JF. 2017. Biogeochemical cycling and phyto-and bacterioplankton communities in a large and shallow tropical lagoon (Términos Lagoon, Mexico) under 2009-2010 El Niño Modoki drought conditions. Biogeosci 14 (4): 959-975. DOI: 10.5194/bg-14959-2017.

Cutrim MVJ, Ferreira FS, Duarte dos Santos AK, Cavalcanti LF, Araújo BdeO, de Azevedo-Cutrim ACG, Furtado JA, Oliveira ALL. 2019. The trophic state of an urban coastal lagoon (northern Brazil), seasonal variation of the phytoplankton community, and environmental variables. Estuar Coast Shelf Sci 216: 98-109. DOI: 10.1016/j.ecss.2018.08.013.

Damar A, Colijn F, Hesse KJ, Kurniawan F. 2020. Coastal phytoplankton pigments composition in three tropical estuaries of Indonesia. J Mar Sci Eng 8: 311. DOI :10.3390/jmse8050311.

de Barros GP, Marques WC, Kirinus EDP. 2014. Influence of the freshwater discharge on the hydrodynamics of Patos Lagoon, Brazil Int J Geosci 5: 925-942.

Dewi R, Zainuri M, Anggoro S, Winanto T. 2019. A Spatio-temporal analysis of the composition and abundance of phytoplankton in Segara Anakan Lagoon Area. IOP Conf Ser: Earth and Environ Sci 406: 012028. DOI: 10.1088/1755-1315/406/1/012028

Dimenta RH, Khairul, Machrizal R. 2018. Studi keanekaragaman plankton sebagai pakan alami udang pada perairan ekosistem mangrove Belawan, Sumatera Utara. Jurnal Pembelajaran dan Biologi Nukleus 4 (2): 18-23.

Effendi H, Kawaroe M, Lestaria DF, Mursalin, Permadi T. 2016 Distribution of phytoplankton diversity and abundance in Mahakam Delta, East Kalimantan. Proc Environ Sci 33: 496-504. DOI: 10.1016/j.proenv.2016.03.102.

Effiong KS, Inyang AI. 2016. Diversity of phytoplankton in Iragbo Part of Yewa Lagoon, Southwest, Nigeria. Am J BioSci 4 (4): 41-48. DOI 10.11648/j.ajbio.20160404.11

Gamito S, Coelho S, Pérez-Ruzafa A. 2019. Phyto- and zooplankton dynamics in two ICOLLs from Southern Portugal. Estuar Coast Shelf Sci 216: 110-117. DOI: 10.1016/j.ecss.2017.11.023

Giripunje MD, Fulke AB, Khairnar K, Meshram PU, Paunikar WN. 2013 A review of phytoplankton ecology in freshwater lakes of India. Lakes Reserv Ponds 7 (2): 127-141.

Gophen M. 2019. Relation Significance between hydrological residence time and phytoplankton dynamics in Lake Kinneret (Israel). Open J Ecol 9 (11): 179-492. DOI: 10.4236/oje.2019.911031.

Gracia-Escobar MF, Millán-Núñez R, González-Silvera A, Santamaríadel-Ángel E, Camacho-Ibar VF, Trees CC. 2014. Changes in the abundance and composition of phytoplankton in a coastal lagoon during neap-spring tide conditions. Open J Mar Sci 4 (2): 80-100. DOI: $10.4236 /$ ojms.2014.42010.
Filippino KC, Mulholland MR, Bernhardt PW. 2011. Nitrogen uptake and primary productivity rates in the Mid-Atlantic Bight (MAB). Estuar Coast Shelf Sci 91: 13-23. DOI: 10.1016/j.ecss.2010.10.001.

Flöder S, Urabe J, Kawabata Z. 2002. The influence of fluctuating light intensities on species composition and diversity of natural phytoplankton communities. Oecologia 133: 395-401. DOI: 10.1007/s00442-002-1048-8.

Frontier S. 1985. Diversity and Structure in Aquatic Ecosystems. Aberdeen University Press, London.

Harlan J. 2018. Analisis Regresi Linear. Universitas Gunadarma, Depok. [Indonesian]

Hasani Q, Adiwilaga EM, Pratiwi NTM. 2012. The relationship between the Harmful Algal Blooms (HABs) phenomenon with nutrients at shrimp farms and fish cage culture sites in Pesawaran District Lampung Bay. Makara J Sci 16 (3): 183-191.

Hasudungan F, Sutaryo D, Giyanto, Sualia I, Wibisono I, Ilman M, Muslihat L. 2008. Ekosistem Laguna Teluk Belukar. Wetlands International-Indonesia Programme, Bogor. [Indonesia]

Hemraj DA, Hossain A, Ye G, Qin J, Leterme SC. 2017. Anthropogenic shift of planktonic food web structure in a coastal lagoon by freshwater flow regulation. Sci Rep 7: 44441. DOI: 10.1038/srep44441.

Jeyaraj N, Joseph S, Arun, Suhaila A, Divya L, Ravikumar S. 2014. Distribution and abundance of zooplankton in estuarine regions along with the Northern Kerala, Southwest Coast of India. Ecologia 4: 2643. DOI: 10.3923/ecologia.2014.26.43.

Kadim MK, Pasisingi N, Kasim F. 2018. Spatial and temporal distribution of phytoplankton in Gorontalo Bay, Indonesia. AACL Bioflux 11 (3): 833-845.

Kjerfve B. 1994. Coastal lagoons. In: Kjerfve B (eds), Coastal Lagoon Processes. Elsevier Oceanography Series, Netherlands.

Krebs CJ. 2014. Ecological Methodology. 3rd ed. Harper Collins Publisher, New York.

Medina-Gómez I, Kjerfve B, Mariño I, Herrera-Silveira J. 2014. Sources of salinity variation in a coastal lagoon in a Karst Landscape. Estuar Coast 37: 1329-1342. DOI: 10.1007/s12237-014-9774-9.

Mentzafou A, Dimitriou E. 2019. Nitrogen loading and natural pressures on the water quality of a shallow Mediterranean Lake. Sci Total Environ 646 (2019): 134-143. DOI: 10.1016/j.scitotenv.2018.07.249.

Mialet B, Gouzou J, Azémar F, Maris T, Sossou C, Toumi N, Van Damme S, Meire P, Tackx M. 2011. The response of zooplankton to improving water quality in the Scheldt estuary (Belgium). Estuar Coast Shelf Sci 93 (1): 47-57.

Mirón MIBD, Castellanos-Páez ME, Garza-Mouriño G, Ferrara-Guerrero MJ, Pagano M. 2014. Spatiotemporal variations of the zooplankton community in a shallow tropical brackish lagoon (Sontecomapan, Veracruz, Mexico). Theor Chem Acc 53 (1): 1-18. DOI: 10.1186/s40555-014-0059-6.

Muhtadi A, Yunasfi, Rais FF, Azmi N, Ariska D. 2015. Biological community structure of Danau Pondok Lapan Langkat Regency, North Sumatera Province. Acta Aquat 2 (2): 83-89. DOI: 10.29103/aa.v1i1.299

Muhtadi A, Yunasfi, Leidonald R, Sandy SD, Junaidy A, Daulay AT. 2016. Limnological status of Lake Siombak, Medan, North Sumatra. Oseanologi dan Limnologi di Indonesia 1 (1): 39-55. DOI: 10.14203/oldi.2016.v1i1.16.

Muhtadi A, Harahap ZA, Leidonald R. 2017a. Morphometry dynamical of siombak lake, Medan Indonesia. Omni-Akuatika 13 (2): 48-56. DOI: 10.20884/1.oa.2017.13.2.174

Muhtadi A, Dhuha OR, Desrita, Siregar T, Muammar M. 2017b. Habitat conditions and diversity of necton in the catchman area of Batangtoru river, Langkat Regency, North Sumatra Province. Depik 6 (2): 90-99. DOI: 10.13170/depik.6.2.5982.

Mukherjee M, Suresh VR, Manna RK. 2018. Microplankton dynamics of a coastal lagoon, Chilika: Interactive effect of environmental parameters on microplankton groups. Environ Monit Assess 190 (11): 1-15. DOI: $10.1007 / \mathrm{s} 10661-018-7049-9$.

Nassar MZA, Gharib SM. 2014. Spatial and temporal patterns of phytoplankton composition in Burullus Lagoon, Southern Mediterranean Coast, Egypt. Egypt J Aquat Res 40 (2): 133-142. DOI: 10.1016/j.ejar.2014.06.004.

Obolewski K, Glińska-Lewczuk K, Bąkowska M, Szymańska M, Mrozińska N. 2018. Patterns of phytoplankton composition in coastal lakes differed by connectivity with the Baltic Sea. Sci Total Environ 631-632: 951-961. DOI: 10.1016/j.scitotenv.2018.03.112. 
Odum EP, Barrett GW. 2005. Fundamentals of Ecology (5th ed.) Brooks/Cole Publishing Co, USA.

Onyema IC. 2008. A checklist of phytoplankton species of the Iyagbe Lagoon, Lagos. Fish Aquat Sci 3 (3): 167-175. DOI: 10.1146/annurev.ecolsys.110308.120220

Öterler B. 2018. Daily vertical variation in phytoplankton composition of a drinking water reservoir (Kadiköy Reservoir Edirne) during summer stratification. Trak Univ J Nat Sci 19 (1): 21-31. DOI: 10.23902/trkjnat.356711

Örnólfsdóttir EB, Lumsden SE, Pinckney JL. 2004. Phytoplankton community growth-rate response to nutrient pulses in a shallow turbid estuary, Galveston Bay, Texas. J Plankton Res 26 (3): 325-339. DOI: 10.1093/plankt/fbh035

Paturej E, Gutkowska A, Koszałka J, Bowszys M. 2017. Effect of physicochemical parameters on zooplankton in the brackish, coastal Vistula Lagoon. Oceanol 59 (1): 49-56. DOI 10.1016/j.oceano.2016.08.001

Pennak RW. 1989. Fresh-Water Invertebrates of The United States: Protozoa to Mollusca. John Wiley \& Sons, Inc, Toronto.

Pereira LCC, Jiménez JA, Koening ML, Neto FFP, Medeiros C, da Costa MM. 2005. Effect of coastline properties and wastewater on plankton composition and distribution in a stressed environment on the north coast of Olinda-PE (Brazil). Braz Archives Biol Technol 48 (6) 1013-1026.

Pérez-Ruzafa A, Marcos C, Pérez-Ruzafa IM, Pérez-Marcos M. 2011. Coastal lagoons: 'Transitional Ecosystems' between transitional and coastal waters. J Coast Conserv 15 (3): 369-392. DOI: $10.1007 / \mathrm{s} 11852-010-0095-2$

Pérez-Ruzafa A, Campillo S, Fernández-Palacios JM, García-Lacunza A, García-Oliva M, Ibañez H, Navarro-Martínez PC, Pérez-Marcos M, Pérez-Ruzafa IM, Quispe-Becerra JI, Sala-MireteA, Sánchez O, Marcos C. 2019. Long-term dynamic in nutrients, chlorophyll a, and water quality parameters in a coastal lagoon during a process of eutrophication for decades, a sudden break and a relatively rapid recovery. Front Mar Sci 6 (2): 1-23. DOI: 10.3389/fmars.2019.00026

Pérez-Ruzafa A, Morkune R, Marcos C, Pérez-Ruzafa IM, RazinkovasBaziukas A. 2020. Can an oligotrophic coastal lagoon support high biological productivity? Sources and pathways of primary production. Mar Environ Res 153: 104824. DOI: 10.1016/j.marenvres.2019.104824

Pratiwi NTM, Ayu IP, Hariyadi S, Mulyawati D, Iswantari A. 2018a. Phytoplankton community in lake Ebony, Pantai Indah Kapuk, North Jakarta. IOP Conf Ser: Earth Environ Sci 149 (1): 1-9. DOI: 10.1088/1755-1315/149/1/012051

Pratiwi NTM, Imran Z, Hariyadi S, Meidwilestari R. 2018b. Suitability of the various diversity index of phytoplankton in Garden House-Coastal Ornamental Lake, Pantai Indah Kapuk, North Jakarta. IOP Conf Ser: Earth Environ Sci 176 (2018): 012047. DOI: 10.1088/17551315/176/1/012047

Qurban MA, Wafar M, Jyothibabu R, Manikandana KP. 2017. Patterns of primary production in the Red Sea. J Mar Syst 169: 87-98. DOI: 10.1016/j.jmarsys.2016.12.008

Rahman R, Pratiwi NTM, Hariyadi S. 2016. The structure of phytoplankton communities in Lake Toba, North Sumatra. Jurnal Ilmu Pertanian Indonesia 21 (2): 120-127

Ratnayake AS, Ratnayake NP, Sampei Y, Vijitha AVP, Jayamali SD 2018. Seasonal and tidal influence for water quality changes in coastal Bolgoda Lake system, Sri Lanka. J Coast Conserv 22 (6): 1191-1199. DOI: 10.1007/s11852-018-0628-7

Rice EW, Baird RB, Eaton AD. 2017. Standard Methods for the Examination of Water and Wastewater ed-23rd. American Public Health Association (APHA), American Water Works Association (AWWA) and Water Environment Federation (WEF), Washington DC.

Rodellas V, Stieglitz TC, Andrisoa A, Cook P, Raimbault P, Tamborski JJ, van Beek P, Radakovitch O. 2018. Groundwater-driven nutrien inputs to coastal lagoons: The relevance of lagoon water recirculation as a conveyor of dissolved nutrients. Sci Total Environ 642 (2018): 764-780. DOI: 10.1016/j.scitotenv.2018.06.095

Romagnan J-B, Legendre L Guidi L, Jamet J-L, Jamet D, Mousseau L, Pedrotti M-L, Picheral M, Gorsky G, Sardet C, Stemmann L. 2015 Comprehensive model of annual plankton succession based on the whole-plankton time series approach. PLoS ONE 10 (3): e0119219. DOI: 10.1371/journal.pone.0119219

Sahu BK, Srichandan S, Panigrahy RC. 2016. A preliminary study on the microzooplankton of Chilika Lake, a brackish water lagoon on the east coast of India. Environ Monit Assess 188 (1): 1-14. DOI: 10.1007/s10661-015-5062-9

Sidabutar T, Bengen DG, Wouthuyzen S, Partono T. 2016. The abundance of phytoplankton and its relationship to the N/P ratio in Jakarta Bay, Indonesia. Biodiversitas 17 (2): 673-678

Srichandan S, Kim JY, Bhadury P, Barik SK, Muduli PR, Samal RN, Pattnaik AK, Rastogi G. 2015. Spatiotemporal distribution and composition of phytoplankton assemblages in a coastal tropical lagoon: Chilika, India. Environ Monit Assess 187: 47. DOI: 10.1007/s10661-014-4212-9

Stander JM. 1970. Diversity and Similarity of Benthic Fauna off Oregon. [Thesis]. Oregon State University, UK.

Sujitha SB, Jonathan MP, Escobedo-Urías DC, Aguirre-Bahena F, Villegas LEC, Muñoz-Sevilla NP. 2017. Spatial variability of inorganic nutrients and physical parameters in the waters of Bahia Magdalena lagoon, Pacific Coast, Mexico. Acta Ecol Sinica 37: 187194. DOI: 10.1016/j.chnaes.2017.01.003.

Sulastri, Henny C, Nomosatryo S. 2019. Phytoplankton diversity and trophic status of Lake Maninjau, West Sumatra, Indonesia. Prosiding Seminar Nasional Masyarakat Biodiversitas Indonesia. Universitas Sebelas Maret, Surakarta, 3 November 2018.

Sulawesty F. 2019. Phytoplankton characteristics in Lake Matano, Indonesia. IOP Conf Ser: Earth Environ Sci. 308: 012072. DOI: $10.1088 / 1755-1315 / 308 / 1 / 012072$

Takarina ND, Nurliansyah W, Wardhana W. 2019. Relationship between environmental parameters and the plankton community of the Batuhideung Fishing Grounds, Pandeglang, Banten, Indonesia. Biodiversitas 20 (1): 171-180. DOI: 10.13057/biodiv/d200120

Tomas RC. 1997. Identifying Marine Phytoplankton. Academic Press, New York.

Torres-Bejarano FM, Torregroza-Espinosa AC, Martínez-Mera E, Castañeda-Valbuena D, Tejera-González MP. 2020. Hydrodynamics and water quality assessment of a coastal lagoon using environmental fluid dynamics code explorer modeling system. Global J Environ Sci Manage 6 (3): 289-308.

Yang C, Nan J, Li J. 2019. Driving factors and dynamics of phytoplankton community and functional groups in an estuary reservoir in the Yangtze River, China. Water 11: 1184. DOI: 10.3390/w11061184

Yilmaz N, Yardimci CH, Elhag M, Dumitrache CA. 2018. Phytoplankton composition and water quality of Kamil Abduş Lagoon (Tuzla Lake), Istanbul-Turkey. Water 10 (5): 1-13. DOI: 10.3390/w10050603

Yudhatama BK, Redjeki S, Suryono CA. 2019. Distribusi Horizontal Zooplankton berdasarkan Salinitas di Perairan Bonang Kabupaten Demak, Indonesia. J Mar Res 8 (3): 322-327. [Indonesia]

Wetzel RG. 2001. Limnology Lake and River Ecosystem Third Edition. Academic Press, London.

Waya RK, Limbu SL, Ngupula GW, Mwita CJ, Mgaya YD. 2017. Temporal patterns in phytoplankton, zooplankton and fish composition, abundance, and biomass in Shirati Bay, Lake Victoria, Tanzania. Lakes and Reservoirs: Res and Manag 2017 22: 19-42. DOI: $10.1111 /$ re. 12161

Wiyarsih B, Endrawati H, Sedjati S. 2019. Komposisi dan Kelimpahan Fitoplankton di Laguna Segara Anakan, Cilacap, Buletin Oseanografi Marina 8 (1): 1-8. DOI: 10.14710/buloma.v8i1.21974. [Indonesia]

Wu JT, Chou TL. 2003. Silicate as the limiting nutrient for phytoplankton in a subtropical eutrophic estuary of Taiwan. Estuar Coast Shelf Sci 58 (1): 155-162. DOI: 10.1016/S0272-7714(03)00070-2 